\title{
ANALISIS PENGARUH RASIO KEUANGAN TERHADAP HARGA SAHAM PADA PERBANKAN YANG TERDAFTAR DI BURSA EFEK INDONESIA
}

\author{
wulan wahyuni ${ }^{{ }^{*}}$, Nilda Tartilla ${ }^{2}$ \\ wulan@ibik.ac.id ${ }^{1 *}$, nildatartilla@gmail.com
}

\begin{abstract}
The purpose of this study is to test, analyze how big the effect of financial ratios on stock prices in banks listed on the Indonesia Stock Exchange, how the influence of Return On Assets (ROA), Debt Equity Ratio (DER), Price Book Value (PBV) and Net Profit Margin (NPM) against stock prices. This research method uses a descriptive method, which is a method to describe and analyze research results but is not used to make broader conclusions. The population of this study are manufacturing companies listed on the Indonesia Stock Exchange (IDX) with the banking sector. The sample was determined using purposive sampling method. The analytical method used in this research is multiple regression with SPSS version 25 program, hypothesis testing is done using multiple linear regression method. The result of this research is partially PBV has a positive effect on stock prices with a significance value of 0.000 , while ROA does not have a positive effect on stock prices with a significance value of 0.272. DER has no effect on stock prices with a significance value of 0.936 and NPM has no effect on stock prices with a significance value of 0.518. Simultaneously ROA, DER, PBV and NPM affect stock prices in banks listed on the Indonesia Stock Exchange. The limitations of this study are the limitations of the data processed and the limitations of the variables used. This research is expected to provide benefits for the community, one of which is for investors or investors as a factor of consideration in investing in the company's capital.
\end{abstract}

\section{Keyword : ROA, DER, NPM, PBV, Stock Price}

\section{PENDAHULUAN}

Bursa Efek Indonesia atau dikenal dengan BEI berfungsi untuk menyediakan fasilitas perdagangan surat berharga atau efek di pasar modal Indonesia, BEI juga berfungsi melakukan kontrol terhadap perdagangan efek. Dengan adanya BEI sebagai pasar modal berperan penting bagi perekonomian suatu negara karena salah satunya sebagai sarana pendanaan, perusahaan dapat mendapatkan dana dari investor sebagai penambah modal kerja atau pengembangan usahanya.

Dalam rangka menarik para investor, perusahaan akan selalu menjaga harga saham nya di pasar modal. Harga saham harus dijaga seoptimal mungkin, harga saham tidak boleh terlalu tinggi atau terlalu rendah. Harga saham terlalu rendah akan berdampak buruk terhadap penilaian para investor terhadap perusahaan.

Harga saham berhubungan erat dengan nilai perusahaan, harga saham yang tinggi akan membuat nilai perusahaan juga ikut tinggi. Nilai perusahaan akan menunjukkan tingkat keberhasilan perusahaan dan akan meningkatkan kepercayaan investor terhadap kinerja perusahaan baik pada kinerja perusahaan saat sekarang atau pun pada masa yang akan datang.

Berikut terdapat data perkembangan harga saham pada lembaga keuangan bank yang terdaftar pada BEI periode $2014-2017$ :

Perkembangan Harga Saham

\begin{tabular}{|l|r|r|r|r|}
\hline Tahun & 2014 & 2015 & 2016 & 2017 \\
\hline
\end{tabular}




\begin{tabular}{|l|r|r|r|r|} 
& & & \\
Harga Saham & $23,76 \%$ & $22,55 \%$ & $25,85 \%$ & $27,84 \%$ \\
\hline
\end{tabular}

Sumber : data diolah, 2021

Apabila digambarkan dengan grafik sebagai berikut :

Grafik Perkembangan Harga Saham

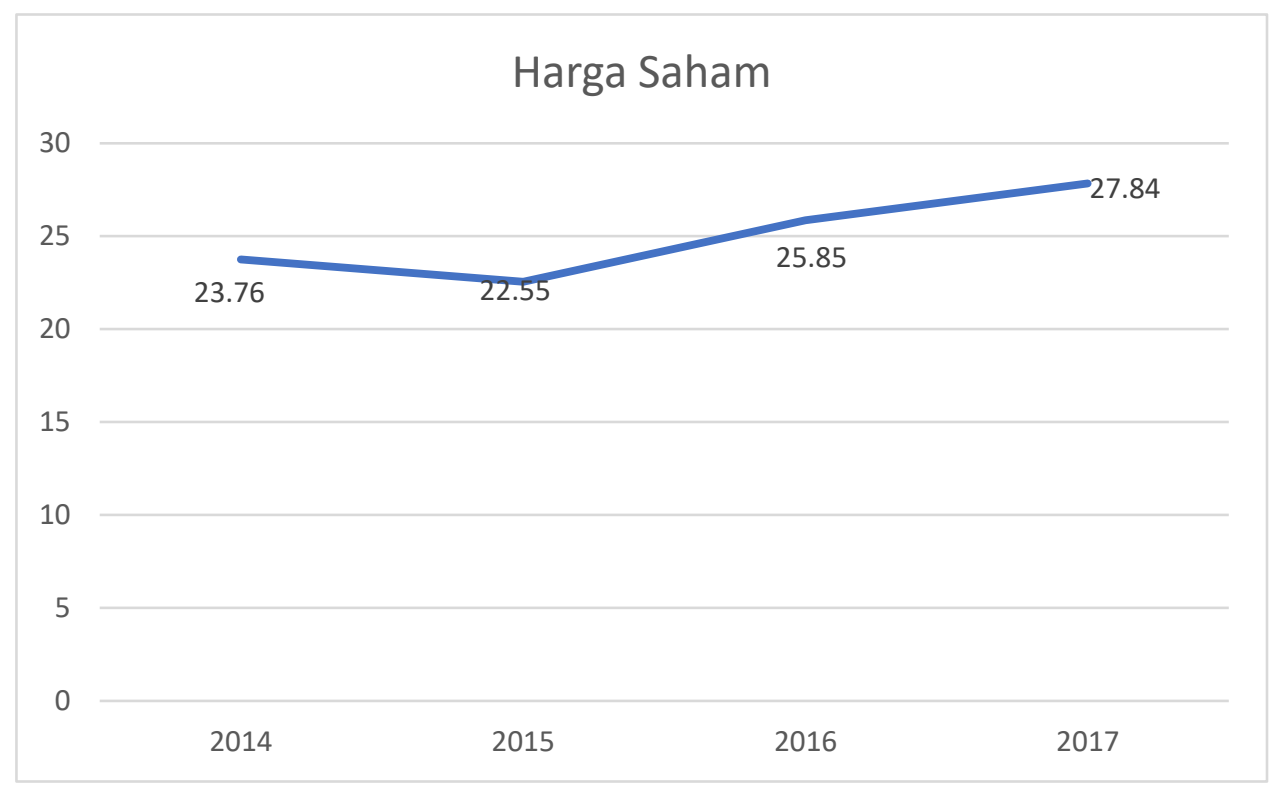

Gambar 1.1

Berdasarkan grafik di atas, menunjukkan harga saham lembaga keuangan bank periode 2015 mengalami penurunan. Pada tahun 2014 sebesar 23,76\% dan tahun 2015 sebesar 22,55\% , penurunan sebesar 1,21\%. Sedangkan pada tahun 2016 dan 2017 mengalami kenaikan, walaupun penurunan pada tahun 2014 tidak terlalu besar, tetapi terdapat faktor yang berpengaruh terhadap penurunan harga saham lembaga keuangan tersebut. Diantaranya rasio -rasio keuangan perusahaan seperti Return On Asset (ROA), Debt to Equity Ratio (DER), Price Book Value (PBV), dan Net Profin Margin (NPM).

Return On Asset (ROA) merupakan sebuah rasio profitabilitas yang menunjukkan kemampuan perusahaan dalam memperoleh laba bersih setelah pajak dari asset yang digunakan oleh perusahaan, ROA diukur dengan membandingkan laba bersih setelah bunga dan pajak dengan total asset perusahaan. Debt Equity Ratio (DER) merupakan rasio solvabilitas yang menunjukkan kemampuan perusahaan dalam memenuhi kewajibannya, DER dapat diukur dengan perbandingan total utang dan total equity. Price Book Value (PBV) merupakan rasio yang digunakan untuk mengukur laba bersih yang dihasilkan oleh setiap penjualan, PBV dihitung dengan cara membagi harga saham dengan nilai buku per saham, kemudian membagi nilai ekuitas dengan jumlah saham yang beredar. Net Profit Margin ( NPM ) merupakan rasio profitabilitas yang menunjukkan berapa besar persentasi laba bersih yang diperoleh dari setiap penjualan, NPM diukur dengan perbandingan laba bersih setelah pajak dengan penjualan bersih.

Penelitan yang dilakukan oleh Rescyana Putri Hutami (2012) menyatakan bahwa Return On Equity (ROE) dan NPM berpengaruh positif dan signifikan terhadap harga saham perusahaan, penelitian yang dilakukan oleh Putu Dina (2013) menyatakan bahwa PBV berpengaruh terhadap harga saham. Menurut Aditya Pratama (2014) DER berpengaruh positif terhadap harga saham sedangkan ROE dan NPM tidak berpengaruh terhadap harga saham. Sedangkan penelitian menurut Robert Lambey (2014) ROA berpengaruh positif terhadap harga saham.

Berdasarkan uraian di atas, maka peneliti mengambil judul penelitian "Analisis Pengaruh Rasio Keuangan Terhadap Harga Saham pada Perbankan yang Terdaftar di Bursa Efek Indonesia”.

\section{TINJAUAN PUSTAKA DAN PENGEMBANGAN HIPOTESIS}




\section{Seminar Ilmiah Sistem Informasi Manajemen dan Akuntansi (SISIMA) 2021}

Menurut Sartono (2019:192) Harga saham dihasilkan melalui mekanisme permintaan dan penawaran saham di pasar modal, apabila permintaan akan saham mengalami kenaikan maka harga saham akan cenderung naik.

Menurut Hery (2014:22) analisis rasio keuangan adalah : “ alat analisis keuangan yang pada umumnya digunakan dengan hasil yang memerlukan interpretasi tidak mudah, rasio harus diinterpretasikan dengan hati - hati karena faktor - faktor saling mempengaruhi antara pembilang dengan penyebutnya". Return On Asset merupakan alat analisis rasio yang menggambarkan perputaran aktiva diukur dari penjualan. Semakin besar rasio ini, maka semakin baik dan hal ini berarti bahwa aktiva dapat lebih cepat berputar dan meraih laba. Jadi, semakin tinggi persentase rasio Return On Asset (ROA), maka semakin baik penggunaan aset secara efisien unuk memperoleh keuntungan bersih dalam kegiatan operasional perusahaan. Hal ini selanjutnya meningkatkan daya tarik perusahaan yang menjadikan perusahaan tersebut makin diminati investor, karena tingkat perolehan pengembalian atas investasi aset akan semakin besar. Sebaliknya, semakin rendah persentase rasio ini dari rasio rata-rata maka daya tarik investor semakin menurun, karena membuat tingkat perolehan pengembalian atas investasi akan semakin kecil. (Harahap, $2010: 305$ ).

Return On Asset (ROA) berfungsi sebagai alat pengawasan sebagai kepentingan perencanaan, misalnya Return On Asset (ROA) dapat digunakan sebagian dasar untuk pengembalian keputusan jika perusahaan akan mengadakan ekspansi. Return On Asset (ROA) juga dapat digunakan untuk mengukur profitabilitas dari masing-masing produk yang dihasilkan perusahaan. (Munawir, 2014).

Rumus ROA :

ROA $=\frac{\text { Laba Bersih X }}{\text { Total Asset }} 100 \%$

Debt To Equity Ratio (DER) merupakan rasio yang digunakan untuk memulai hutang dengan ekuitas. DER dihitung dengan cara membandingkan antara seluruh hutang, termasuk utang lancar dengan seluruh ekuitas. Rasio ini berguna untuk mengetahui jumlah dana yang disediakan krediut dengan pemilik perusahaan. DER berfungsi untuk mengetahui setiap jumlah rupiah modal sendiri yang dijadikan untuk jaminan hutang dan menggambarkan sampai sejauh mana modal pemilik dapat menutupi hutang-hutang kepada pihak luar. ( Kasmir, $2017: 157$-158).

Menurut Agnes (2015:13) DER berfungsi untuk mengukur seberapa besar operasional perusahaan dibiayai oleh kreditur, makin tinggi rasio ini maka akan semakin besar pembiayaan yang dihasilkan oleh perusahaan.

Rasio DER dapat dirumuskan sebagai berikut :

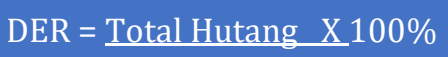

Modal Sendiri

Price Book Value (PBV) merupakan salah satu indikator dalam analisis nilai perusahaan yang menunjukkan bahwa harga saham dapat diperdagangkan melalui overhead dengan buku saham.

PBV dapat dirumuskan sebagai berikut :

PBV $=\underline{\text { Market Price Per Share }}$

Book Value Per Share

NPM merupakan perbandingan laba bersih dan penjualan. Rasio NPM akan menunjukkan seberapa besar persentasi laba bersih yang diperoleh dari setiap penjualan. (Kasmir, 2016 : 199)

NPM dapat dirumuskan sebagai berikut :

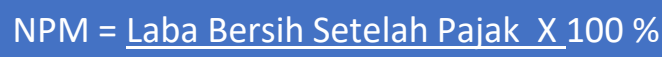

Penjualan 
Kerangka pemikiran teoritis pada penelitian ini adalah sebagai berikut :

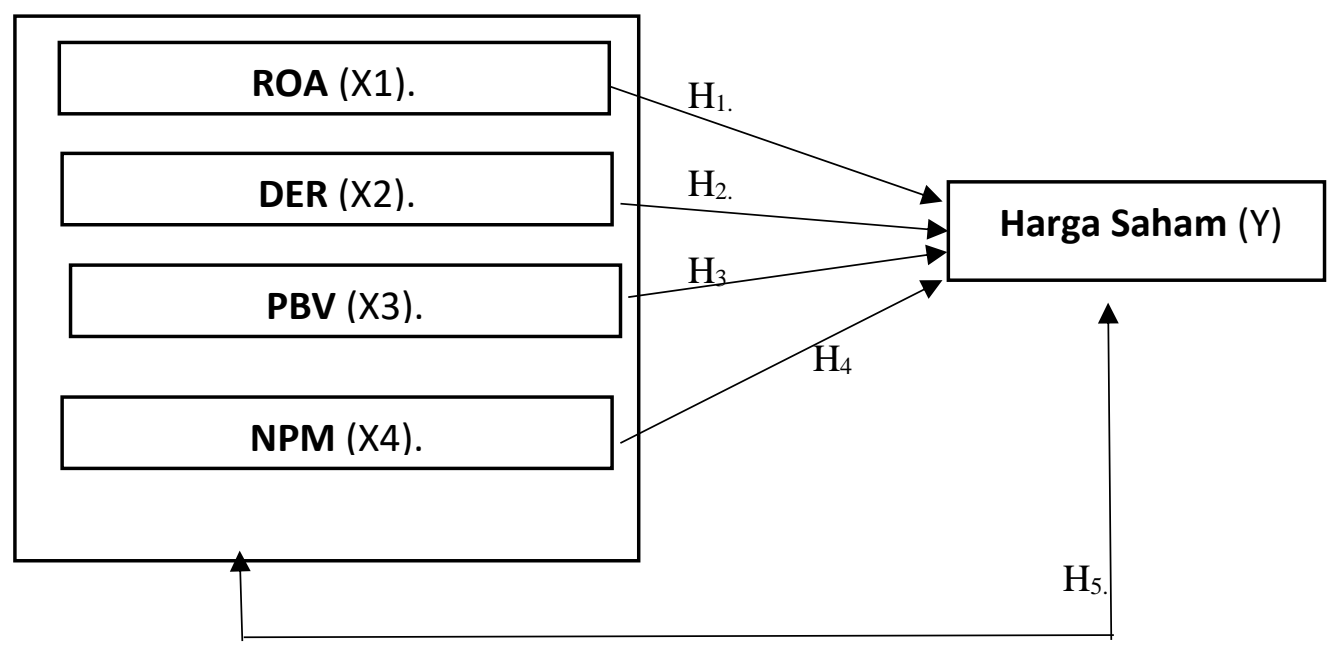

Pengembangan Hipotesis

1. Pengaruh Return On Asset (ROA) Terhadap Harga Saham

Return On Asset (ROA) dapat digunakan untuk mengukur rasio profitabilitas yaitu rasio bagaimana perusahaan berkemampuan untuk mendapatkan laba. Maka semakin tinggi rasio ROA akan menunjukkan semakin tinggi pula tingkat keuntungan yang diperoleh perusahaan. Tingkat keuntungan akan meningkatkan nilai perusahaan sehingga akan meningkatkan harga saham. Berdasarkan uraian tersebut, maka hipotesis yang diajukan :

H1 : Return On Asset berpengaruh positif terhadap Harga Saham

\section{Pengaruh Debt Equity Ratio ( DER ) Terhadap Harga Saham}

Menurut Brealey, Myers dan Marcus (2010 :7) semakin tinggi nilai Debt Equity Ratio (DER) maka akan mengindikasi perusahaan tidak mampu mengelola hutang secara baik dengan ekuitas yang dimiliki perusahaan. Dengan utang dapat menyebabkan kondisi meningkatkan atau mengurangi pengembalian bagi pemegang saham sehingga akan mempengaruh tingkat harga, tetapi dalam kondisi perusahaan tidak menghasilkan laba, maka kecenderungan hutang akan mempengaruhi pengurangan pengembalian terhadap pemegang saham sehingga akan mempengaruhi harga saham. Berdasarkan uraian terebut maka hipotesis yang diajukan :

H2 : Debt Equity Ratio ( DER ) berpengaruh negatif terhadap Harga Saham

\section{3. $\quad$ Pengaruh Price Book Value ( PBV ) Terhadap Harga Saham}

Price Book Value (PBV) merupakan rasio pasar yang membandingkan harga pasar saham dengan nilai buku, PBV sering digunakan sebagai indicator untuk mengukur nilai perusahaan. Semakin tinggi nilai PBV akan menunjukkan nilai perusahaan yang tinggi sehingga akan berpengaruh terhadap harga saham yang tinggi juga. Maka dapat diajukan hipotesis sebagai berikut :

H3 : Price Book To Value ( PBV ) berpengaruh positif terhadap Harga Saham

\section{Pengaruh Net Profit Margin ( NPM ) Terhadap Harga Saham}

Net Profit Margin (NPM) akan menunjukkan seberapa besar persentasi laba bersih yang diperoleh dari setiap penjualannya. Semakin besar NPM maka akan menunjukkan kinerja manajemen yang baik sehingga akan dipercayai oleh investor. Hal ini akan berpengaruh juga terhadap perubahan harga saham yang tinggi. Maka dari itu hipotesis yang dapat diajukan adalah:

H4 : Net Profit Margin ( NPM ) berpengaruh positif terhadap Harga Saham

5. Pengaruh ROA, DER, PBV dan NPM Secara Simultan Berpengaruh Terhadap Harga Saham 


\section{Seminar Ilmiah Sistem Informasi Manajemen dan Akuntansi (SISIMA) 2021}

ROA, DER, PBV dan NPM merupakan indikator untuk analisis rasio keuangan, rasio keuangan dipergunakan oleh perusahaan untuk menilai kinerja perusahaan selama perusahaan berjalan. Sehingga perusahaan dapat mengambil kebijakan keuangan dengan tepat.

ROA , PBV dan NPM sangat dibutuhkan informasinya oleh para pemegang saham, karena akan menunjukkan seberapa besar perusahaan akan menghasilkan laba yang optimal. Dengan ROA, PBV dan NPM yang besar akan menjadi salah satu indicator keberhasilan sebuah perusahaan. Sedangkan analisis rasio DER akan menunjukkan akan menunjukkan seberapa besar jumlah hutang dan modal perusahaan yang akan digunakan sebagai pendanaan.

Telah banyak dilakukan penelitian tentang seberapa besar pengaruh rasio keuangan terhadap harga saham perusahaan. Hal ini dikarenakan untuk lebih mengetahui seberapa besar pengaruh rasio keuangan terhadap harga saham sehingga akan menarik para investor untuk menanamkan modal nya yang pada akhirnya akan meningkatkan harga saham perusahaan. Maka dari itu hipotesis yang diajukan adalah :

H5 : ROA, DER, PBV dan NPM berpengaruh secara simultan terhadap Harga Saham.

3. Metode penelitian

Populasi dan Sampel

Populasi penelitian ini adalah perusahaan manufaktur yang terdaftar di Bursa Efek Indonesia, dengan sampel penelitian sektor Perbankan pada periode 2013 - 2017.

VARIABEL PENELITIAN

Penelitian ini terdiri dari variabel :

1. Variabel Independent

Dalam penelitian ini variabel $\mathrm{X}$ terdiri dari :

1) Return On Asset (ROA)

Rumus ROA yaitu:

\section{ROA $=$ Laba Bersih X 100\% \\ Total Asset}

2) Debt Equity Ratio (DER)

Rumus DER yaitu :

\section{DER $=\underline{\text { Total Hutang } \times 100 \%}$}

Modal Sendiri

3) Price Book Value (PBV)

Dapat digambarkan dengan rumus :

PBV : Market Price Per Share Pajak Book Value Per Share

4) Net Profit Margin (NPM)

Rumus NPM yaitu:

\section{NPM $=$ Laba Bersih Setelah Pajak}

Penjualan Bersih

2. Variabel Dependent

Pada penelitian ini variabel Y adalah Harga Saham. Harga saham merupakan harga selembar saham yang terjadi pada saat tertentu serta harga nya ditentukan oleh permintaan dan penawaran pasar, harga saham yang digunakan dalam penelitian ini adalah harga tertutup (Closing 
Price ) karena dianggap sebagai harga akhir yang stabil dan yang tercantum dalam laporan keuangan tiap akhir tahun.

\section{TEKNIK ANALISIS DATA}

Analisis data pada penelitian ini dimulai dengan uji asumsi klasik, menyusun persamaan regresi linier berganda, kemudian dilakukan, dan uji hipotesis.

\section{Uji Asumsi Klasik}

Uji asumsi klasik yang digunakan dalam penelitian ini adalah :

1. Uji Normalitas

Uji normalitas yang digunakan dalam penelitian ini adalah dengan menggunakan uji Kolmogorovsmirnov program SPSS. Signifikamsi uji Kolmogorov adalah apabila signifikansi dibawah 0,05 berarti terdapat perbedaan yang signifikan dengan data normal baku, sehingga mendapatkan kesimpulan data yang digunakan tidak normal.

\section{Uji Multikolinieritas}

Multikoliniearitas dilakukan dengan tujuan pengujian apakah ada korelasi yang besar atau sempurna antar variabel independen di dalam model regresi. Apabila koefisien regresi variabel independen tidak dapat ditentukan serta nilai standard error tidak terhingga, maka multikolinieritas terjadi dengan sempurna. Dalam mendeteksi apakah terdapat multikolinieritas menggunakan nilai Tolerance dan Variance Inflation Factor (VIF) (Ghozali, 2018). Dalam menemukan ada dan tidaknya multikolinieritas didalam model regression adalah sebagai berikut, VIF (Variance Inflation Factor) dan tolerance petunjuk suatu model regression yang bebas multikolinieritas adalah memperlihatkan angka tolerance di atas $>0,1$ dan memperlihatkan nilai VIF di bawah $<10$

\section{Uji Heteroskedastisitas}

Cara untuk mendeteksi ada atau tidaknya heteroskedastisitas adalah salah satunya dengan melihat grafik plot antara nilai prediksi variabel dependen yaitu ZPRED dengan residualnya SRESID. Deteksi ada tidaknya heteroskedastisitas dapat dilakukan dengan melihat ada tidaknya pola tertentu pada grafik scatterplot antara SRESID dan ZPRED di mana sumbu Y adalah Y yang telah diprediksi, dan sumbu X adalah residual yang telah di-studentized. Jika terdapat pola tertentu seperti titik - titik yang ada membentuk pola tertentu yang teratur maka mengindikasikan telah terjadi heteroskedastisitas, jika tidak ada pola yang jelas, serta titik - titik menyebar di atas dan di bawah angka 0 pada sumbu $\mathrm{Y}$, maka tidak terjadi heteroskedastisitas (Ghozali, 2006:139).

\section{Uji Autokorelasi}

Uji autokorelasi dilakukan guna menilai apakah terdapat korelasi antara periode $\mathrm{t}$ dengan periode sebelumnya t-1 (Imam Ghozali, 2011). Apabila hasil tersebut menunjukan adanya korelasi, maka menunjukan adanya masalah autokorelasi. Secara sederhana, analisis regresi harus terbebaskan dari autokorelasi. Penyimpangan asumsi ini biasanya terjadi pada penelitian yang menggunakan data time series. Dalam menilai ada tidaknya autokorelasi pada model regresi, dapat diuji menggunakan durbin watson (Imam Ghozali, 2011). Dalam pengambilan keputusan untuk melihat ada atau tidaknya autokorelasi dijabarkan sebagai berikut:

1. Jika $\mathrm{d} \leq \mathrm{dl}$ atau $\mathrm{d} \geq 4-\mathrm{dl}$, maka hipotesis nol ditolak, artinya terjadi autokorelasi.

2. Jika $\mathrm{dU} \leq \mathrm{d} \leq 4-\mathrm{dU}$, maka hipotesis diterima, artinya tidak terjadi autokorelasi.

3. Jika $\mathrm{dL} \leq \mathrm{d} \leq \mathrm{dU}$ atau $4-\mathrm{dU} \leq \mathrm{d} \leq 4-\mathrm{dL}$, artinya tidak ada kesimpulan yang diperoleh.

Analisis Regresi Linier Berganda

Regresi linier digunakan untuk mendapatkan hubungan matematis dalam bentuk suatu persamaan antara variabel dependen dengan variabel independen. Bentuk persamaan regresi linier, yaitu :

$$
\mathrm{Y}=\alpha+\beta \mathrm{X}_{1}+\beta \mathrm{X}_{2}+\beta \mathrm{X}_{3}+\beta \mathrm{X}_{4}+\varepsilon
$$

Keterangan :

$\mathrm{Y}=$ Variabel dependen 


\section{Seminar Ilmiah Sistem Informasi Manajemen dan Akuntansi (SISIMA) 2021}

$\alpha=$ Titik potong atau konstanta

$\beta=$ Koefisen regresi

$\mathrm{X}_{1}=$ Variabel ROA

$\mathrm{X}_{2}=$ Variabel DER

$\mathrm{X}_{3}=$ Variabel PBV

$\mathrm{X}_{4}=$ Variabel NPM

$\varepsilon=$ Tingkat error

\section{Uji Hipotesis}

1. Koefisien Determinasi (R2)

Menurut Ghozali (2018), tujuan mengukur koefisien determinasi untuk mengetahui persentase pengaruh variabel independen terhadap perubahan variabel dependen. Dapat dilihat berapa banyak variabel terikat yang dapat dijelaskan oleh variabel bebas, dan sisanya ditentukan oleh alasan lain di luar model. Untuk mengetahuinya, nilai maksimum dapat dicapai dengan membagi nilai Cox dan Snell $\mathrm{R} 2$ dengan nilainya.

1. Jika nilai hasil mendekati 1 , maka menunjukan bahwa variabel independen menyajikan sebagian informasi yang diperlukan untuk menjelaskan variabel dependen

2. Jika mendekati 0, model dianggap tidak baik yang berarti bahwa variabel independen tidak menyajikan informasi yang diperlukan untuk menjelaskan variabel dependen.

2. Uji Hipotesis Secara Simultan (Uji F)

Uji ini dilakukan untuk menunjukkan apakah seluruh variabel independen memiliki pengaruh terhadap variabel dependen secara bersamaan dalam model, yang akan ditunjukkan dengan tingkat signifikan sebesar 0,05 (Ghozali, 2018). Dasar pengambilan keputusan untuk uji simultan (Uji F) adalah sebagai berikut:

1. Jika Signifikasi F $>0,05$ maka dapat disimpulkan variabel bebas berpengaruh bersama-sama terhadap variabel terikat

2. Jika signifikasi $F<0,05$ maka disimpulkan bahwa variabel bebas tidak berpengaruh secara bersama-sama terhadap variabel terikat

3. Uji Hipotesis Secara Parsial (Uji t)

Uji T dilakukan untuk melihat seberapa jauh variabel independen berpengaruh secara parsial atau individual terhadap variabel dependen. Yang dapat dilakukan dalam pengambilan keputusan yaitu dengan perbandingan antara $t$ hitung dengan $t$ tabel. Dasar untuk mengambil keputusan pada Uji $t$ ini adalah sebagai berikut:

1. Apabila probabilitas < 0,05 yang artinya variabel independen berpengaruh secara individual terhadap variabel dependen.

2. Apabila probabilitas $>0,05$ artinya variabel independen tidak berpengaruh secara individual terhadap variabel dependen.

4. Hasil dan pembahasan

Hasil Uji Asumsi Klasik

1. Uji Normalitas

Uji normalitas yang digunakan dalam penelitian ini adalah Uji Kolmogorov-Smirnov dengan Monte Carlo yaitu:

One-Sample Kolmogorov-Smirnov Test

\begin{tabular}{rrr} 
& $\begin{array}{c}\text { Unstanda } \\
\text { rdized } \\
\text { Residual }\end{array}$ \\
\hline $\mathrm{N}$ & 50 \\
\hline & Mean & .0000000 \\
\hline
\end{tabular}




\begin{tabular}{|c|c|c|c|}
\hline $\begin{array}{l}\text { Normal } \\
\text { Parameters }\end{array}$ & \multicolumn{2}{|l|}{ Std. Deviation } & $\begin{array}{r}8.783100 \\
72\end{array}$ \\
\hline \multirow{3}{*}{$\begin{array}{l}\text { Most Extreme } \\
\text { Differences }\end{array}$} & \multicolumn{2}{|l|}{ Absolute } & .150 \\
\hline & \multicolumn{2}{|l|}{ Positive } & .150 \\
\hline & \multicolumn{2}{|l|}{ Negative } & -.110 \\
\hline \multicolumn{3}{|l|}{ Test Statistic } & .150 \\
\hline \multicolumn{3}{|c|}{ Asymp. Sig. (2-tailed) } & $.007^{\mathrm{c}}$ \\
\hline \multirow{3}{*}{$\begin{array}{l}\text { Monte Carlo Sig. } \\
\text { (2-tailed) }\end{array}$} & Sig. & & $.191^{\mathrm{d}}$ \\
\hline & \multirow{2}{*}{$\begin{array}{l}99 \% \\
\text { Confidence } \\
\text { Interval }\end{array}$} & $\begin{array}{l}\text { Lower } \\
\text { Bound }\end{array}$ & .181 \\
\hline & & $\begin{array}{l}\text { Upper } \\
\text { Bound }\end{array}$ & .201 \\
\hline
\end{tabular}

a. Test distribution is Normal.

b. Calculated from data.

c. Lilliefors Significance Correction.

d. Based on 10000 sampled tables with starting seed

624387341.

Berdasarkan tabel di atas, dihasilkan 0,191, maka dapat disimpulkan data penelitian tidak terjadi residual atau berdistribusi normal karena nilainya $>0,05$

2. Uji Multikolinearitas

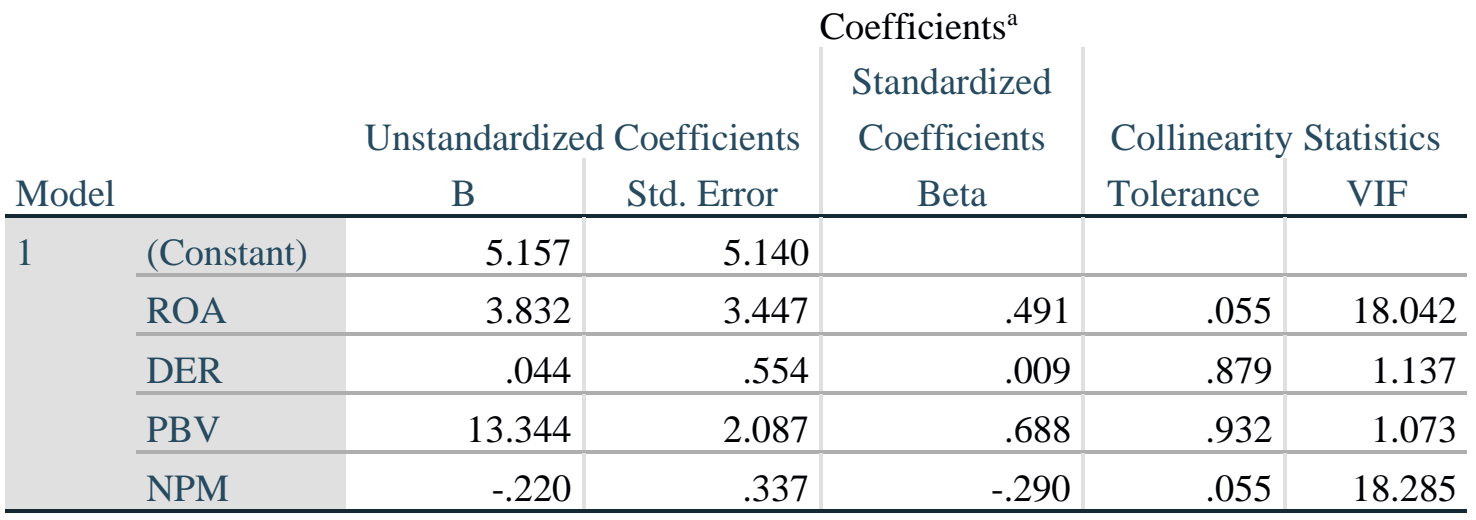

a. Dependent Variable: HS1

Apabila dilihat dari tabel nilai VIF untuk variable ROA diatas 10 dan tolerance di bawah 0,1 maka terjadi multikol, begitupun sama dengan variable NPM. Sedangkan untuk DER dan PBV nilai VIF di bawah 10 dan nilai tolerance di atas 0,1 maka tidak terjadi multikolinearitas.

3. UJI Heteroskedastisitas 


\section{Seminar Ilmiah Sistem Informasi Manajemen dan Akuntansi (SISIMA) 2021}

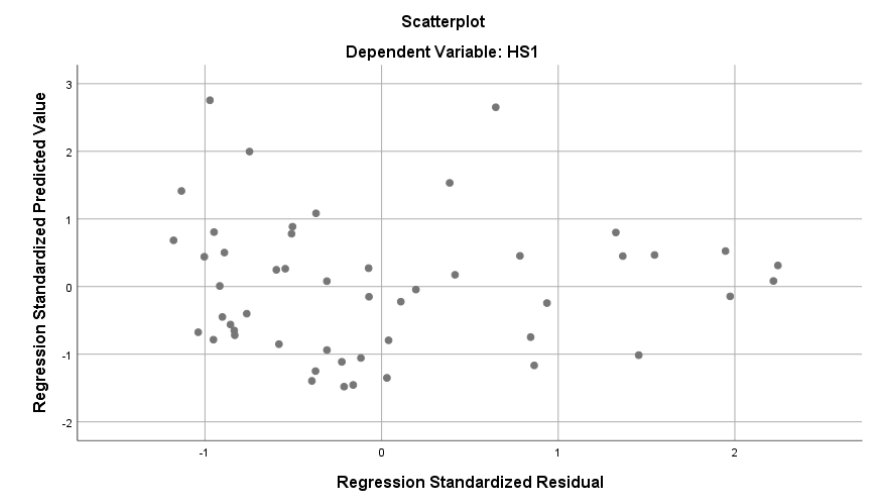

Apabila dilihat dari grafik di atas, terjadi penyebaran titik - titik dan tidak terbentuk suatu pola tertentu maka dapat disimpulkan tidak terjadi heteroskedastisitas.

4. Uji Autokorelasi

\begin{tabular}{|c|c|c|c|c|c|c|}
\hline & & & & & \multicolumn{2}{|c|}{ Model Summary ${ }^{b}$} \\
\hline & \multicolumn{5}{|c|}{ Change Statistics } & \\
\hline $\begin{array}{l}\text { Mo } \\
\text { del }\end{array}$ & $\begin{array}{c}\text { R } \\
\text { Square } \\
\text { Change }\end{array}$ & $\begin{array}{c}\text { F } \\
\text { Chan } \\
\text { ge }\end{array}$ & df1 & df 2 & $\begin{array}{c}\text { Sig. F } \\
\text { Chang } \\
\mathrm{e} \\
\end{array}$ & $\begin{array}{l}\text { Durbin- } \\
\text { Watson }\end{array}$ \\
\hline 1 & .514 & $\begin{array}{r}11.90 \\
0\end{array}$ & 4 & 45 & .000 & 1.494 \\
\hline
\end{tabular}

a. Predictors: (Constant), NPM, PBV, DER, ROA

b. Dependent Variable: HS1

Apabila dilihat berdasarkan data tersebut, maka nilai DW nya 1,494. Nilai DU untuk data sebanyak 50 dan variable 4 adalah 1,7214 dan nilai 4 - du adalah $(4-1,7214=2,2786)$. Sehingga nilai DW terletak diantara du dan 4-du. Maka dapat disimpulkan bahwa model regresi dalam penelitian ini tidak terjadi autokorelasi.

Analisis Regresi Linier.

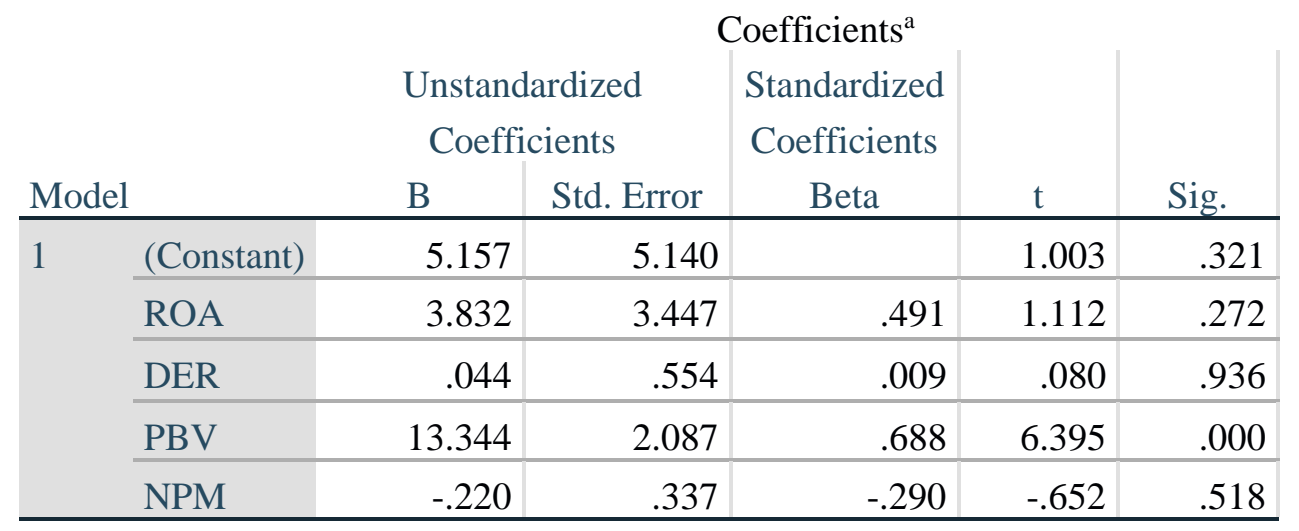

a. Dependent Variable: HS1

Dari data di atas , persamaan regresesi bisa dibuat ke dalam persamaan regresi yaitu: 
$\mathrm{Y}=5.157+3,832 \mathrm{ROA}+0,044 \mathrm{DER}+13,344 \mathrm{PBV}-220 \mathrm{NPM}+\varepsilon$

Dari persamaan di atas dapat dijelaskan yaitu :

1. Konstanta sebesar 5,157 artinya bahwa jika nilai $\mathrm{X} 1, \mathrm{X} 2, \mathrm{X} 3$ dan $\mathrm{X} 4=0$ atau ROA, DER, PBV dan NPM nya 0 , maka nilai variabel y atau harga saham sebesar 5,157.

2. Nilai koefisien ROA sebesar 3,8332 artinya terdapat perbandingan lurus antara variable $\mathrm{X}$ dan $\mathrm{Y}$, yaitu jika ROA bertambah maka harga saham juga ikut bertambah.

3. Nilai koefisien DER sebesar 0,044 artinya terdapat perbandingan lurus antara variable X dan $Y$, yaitu jika DER bertambah maka harga saham akan bertambah

4. Nilai koefisien PBV sebesar 13,344 artinya terdapat perbandingan lurus antara variable $\mathrm{X}$ dan $\mathrm{Y}$, yaitu jika PBV bertambah maka harga saham akan bertambah

5. Nilai koefisien NPM sebesar -0,220 artinya terdapat perbandingan terbalik antara variable X dan Y, yaitu jika NPM bertambah maka harga saham akan turun

Uji T.

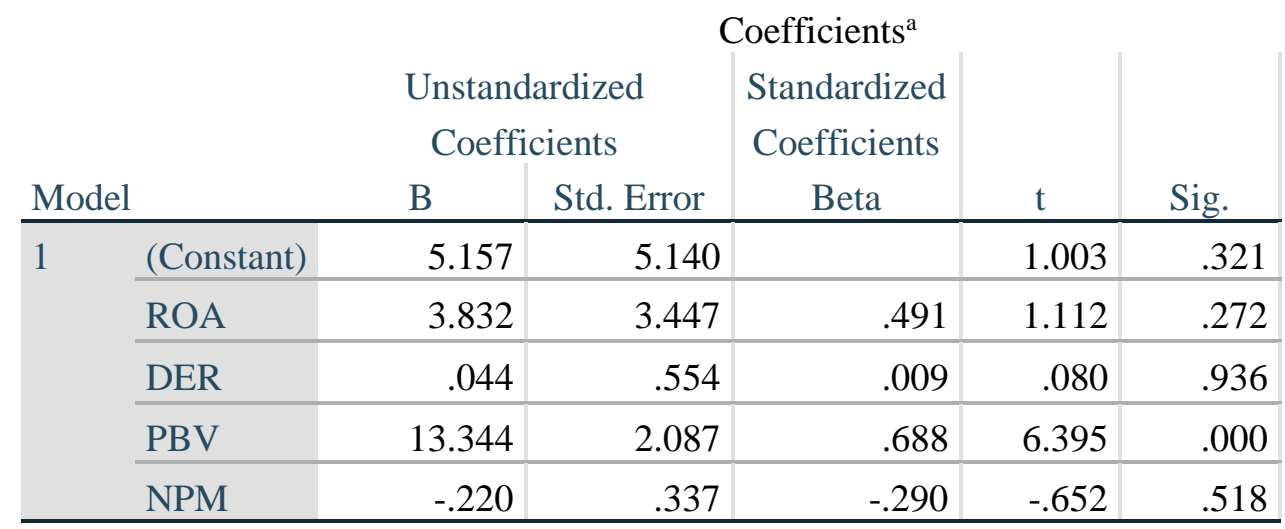

a. Dependent Variable: HS1

Dari data di atas, maka dapat disimpulkan :

1. ROA

Jika diketahui dari besaran nilai Sig ROA sebesar 0,272, sedangkan standard yang ditetapkan adalah 0,05. Maka dari itu menyatakan ROA tidak mempunyai pengaruh terhadap harga saham, begitu juga apabila kita lihat dari nilai thit sebesat 1,112 kecil dari t tabel senilai 1,676. Standard yang ditetapkan seharusnya t hitung $>\mathrm{t}$ tabel.

2. DER

Apabila dilihat dari nilai Sig DER senilai 0,936, lebih besar dari 0,05. Dan t hit. senilai 0,080 < dari t tabel sebesar 1,676. Maka DER tidak memliki pengaruh terhadap harga saham.

3. PBV

Apabila dilihat dari hasil Sig PBV sebesar 0,000 kurang dari standard yang ditetapkan sebesar 0,05. Sedangkan $t$ hit senilai 6,395 lebih besar dari t tabel sebesar 1,676, maka PBV berpengaruh terhadap Harga saham.

4. NPM

Apabila diketahui dari nilai Sig NPM senilai 0,518 kurang dari standard yang ditetapkan sebesar 0,05 . Sedangkan t hit senilai $-0,652$ lebih kecil dari t tabel sebesar 1,676, maka NPM tidak mempunyai pengaruh terhadap Harga saham.

UJI F.

ANOVA $^{\mathrm{a}}$ 


\section{Seminar Ilmiah Sistem Informasi Manajemen dan Akuntansi (SISIMA) 2021}

\begin{tabular}{lll|r|r|r|r} 
Model & \multicolumn{2}{c}{$\begin{array}{l}\text { Sum of } \\
\text { Squares }\end{array}$} & df & Mean Square & F & Sig. \\
\hline \multirow{2}{*}{$1 \quad$ Regression } & 3998.520 & 4 & 999.630 & 11.900 & $.000^{\mathrm{b}}$ \\
\cline { 2 - 7 } & Residual & 3780.000 & 45 & 84.000 & & \\
\cline { 2 - 7 } & Total & 7778.520 & 49 & & & \\
\hline
\end{tabular}

a. Dependent Variable: HS1

b. Predictors: (Constant), NPM, PBV, DER, ROA

Apabila dilihat dari tabel di atas, maka dapat dilihat F hitung sebesar 11,900 Sedangkan F tabel sebesar 2,56. Hal ini berarti $\mathrm{F}$ hitung $>\mathrm{F}$ tabel, sehingga dapat disimpulkan varibel $\mathrm{X}$ secara simultan atau Bersama - sama berpengaruh terhadap variable Y, yaitu variable ROA, DER, PBV dan NPM berpengaruh secara simultan terhadap harga saham.

\section{PEMBAHASAN}

Pengaruh Return On Asset (ROA) terhadap Harga Saham

Return On Asset (ROA) merupakan salah satu dimensi rasio profitabilitas yaitu rasio bagaimana perusahaan berkemampuan untuk mendapatkan laba. Maka semakin tinggi rasio ROA menunjukkan akan makin besar tingkat laba yang diperoleh perusaahaan. Tingkat keuntungan akan meningkatkan nilai perusahaan sehingga akan meningkatkan harga saham. Dari hasil pengujian hipotesis menunjukan yaitu ROA tidak memiliki pengaruh positif terhadap Harga saham, maka dapat dikatakan hipotesis ditolak. Besar kecilnya harga saham tidak dipengaruhi oleh ROA, harga saham tidak selalu ditentukan dengan bagaimana laba perusahaan dihasilkan dari asset yang digunakan. Data ROA untuk perusahaan perbankan pun nilai nya tidak konsisten pada tahun 2013 - 2017.

Hal ini didukung oleh penelitian yang dilakukan oleh Daniarto Rahardjo Dul Muid (2013), dan sejalan juga dengan penelitian yang dilakukan oleh Prasetyo Muktiono Putro (2017).

Pengaruh Debt Equity Ratio (DER) terhadap harga saham.

Menurut Brealey, Myers dan Marcus (2010 :7) semakin tinggi nilai Debt Equity Ratio (DER) maka akan mengindikasi perusahaan tidak mampu mengelola hutang secara baik dengan ekuitas yang dimiliki perusahaan. Dengan utang dapat menyebabkan kondisi meningkatkan atau mengurangi pengembalian bagi pemegang saham sehingga akan mempengaruh tingkat harga, tetapi dalam kondisi perusahaan tidak menghasilkan laba, maka kecenderungan hutang akan mempengaruhi pengurangan pengembalian terhadap pemegang saham Berdasarkan hasil pengujian hipotesis maka dihasilkan DER tidak memiliki pengaruh negatif terhadap harga saham, maka dapat disimpulkan hipotesis ditolak. Besar kecilnya harga saham tidak dipengaruhi oleh kemampuan modal untuk menjamin utang. Hasil penelitian ini didukung oleh penelitian yang dilakukan oleh Putu Dina Arystya (2013). Tetapi penelitian yang dilakukan oleh Aditya Pratama DER berpengaruh terhadap harga saham.

Pengaruh Price Book Value (PBV) terhadap harga saham

Price Book Value (PBV) adalah rasio pasar yang membandingkan harga pasar saham dengan nilai buku, PBV sering digunakan sebagai indikator yang menunujkkan nilai perusahaan. Nilai PBV yang makin besar akan berdampak pada nilai perusahaan yang tinggi sehingga akan berpengaruh terhadap harga saham yang tinggi juga. Menurut hasil uji hipotesis maka dapat dihasilkan Price Book Value (PBV) mempunyai pengaruh positif terhadap harga saham. Maka dapat disimpulkan hipotesis diterima, semakin besar PBV maka harga saham akan mengalami kenaikan. PBV berkaitan dengan indikator untuk menunjukkan nilai perusahaan, dan nilai perusahaan diukur juga dengan saham. Hasil penelitian ini didukung oleh Putu Dina Aristya (2013) bahwa PBV berpengaruh positif terhadap harga saham.

Pengaruh Net Profit Margin (NPM) terhadap harga saham 
Net Profit Margin (NPM) akan menganalisis nilai persentasi laba bersih yang dihasilkan dari setiap penjualannya. NPM akan menunjukkan kinerja manajemen yang baik sehingga akan dipercayai oleh investor. Sehingga akan mempunyai pengaruh juga pada perubahan harga saham yang besar. Berdasarkan hasil pengujian hipotesis maka dapat dihasilkan NPM tidak mempunyai pengaruh positif pada harga saham, maka dapat disimpulkan hipotesis tidak diterima. Harga saham tidak selalu dipengaruhi oleh tingkat pengembalian laba, terdapat beberapa variabel yang berpengaruh seperti kondisi keuangan perusahaan yang kurang stabil.

Hasil penelitian ini didukung oleh Aditya Pratama (2014) menghasilkan NPM tidak mempunyai pengaruh positif terhadap harga saham, sedangkan penelitian yang dilakukan oleh Rescyana Putri. (2012) NPM mempunyai pengaruh positif terhadap harga saham.

ROA, DER, PBV dan NPM Berpengaruh Secara Simultan atau Bersama-sama Terhadap Harga Saham.

ROA, DER, PBV dan NPM merupakan indikator untuk analisis ratio keuangan, ratio keuangan berguna untuk menilai kinerja perusahaan selama perusahaan berjalan. Sehingga perusahaan dapat mengambil kebijakan keuangan dengan tepat.

ROA, PBV dan NPM sangat dibutuhkan informasinya oleh para stake holder, dikarenakan dapat menunjukkan seberapa jauh perusahaan akan menghasilkan profit yang optimal. Dengan ROA, PBV dan NPM yang besar akan menjadi salah satu indicator keberhasilan sebuah perusahaan. Sedangkan analisis rasio DER akan menunjukkan akan menunjukkan seberapa besar total utang dan equity perusahaan yang akan dipakai untuk pembiayaan.

Telah banyak dilakukan penelitian tentang seberapa besar pengaruh rasio keuangan terhadap harga saham perusahaan. Hal ini dikarenakan untuk lebih mengetahui seberapa besar pengaruh rasio keuangan terhadap harga saham sehingga akan menarik para investor untuk menanamkan modal nya yang pada akhirnya akan meningkatkan harga saham perusahaan. Berdasarkan hasil pengujian hipotesis menghasilkan ROA, DER, PBV dan NPM berpengaruh secara simultan atau bersama- sama terhadap harga saham. ROA, DER, PBV dan NPM merupakan komponen yang digunakan untuk mengukur rasio keuangan. Pengukuran rasio keuangan digunakan untuk mengukur kinerja perusahaan. Kinerja perusahaan berhubungan dengan pencapaian nilai perusahaan, dan nilai perusahaan akan terlihat baik apabila harga saham perusahaan mengalami kenaikan.

\section{Kesimpulan}

Kesimpulan atas pengujian yang telah dilaksanakan adalah:

1. ROA tidak terdapat pengaruh terhadap harga saham pada perbankan yang terdaftar di BEI.

2. DER tidak terdapat pengaruh terhadap harga saham pada perbankan yang terdaftar di BEI.

3. PBV terdapat pengaruh terhadap harga saham pada perbankan yang terdaftar di BEI.

4. NPM tidak terdapat pengaruh terhadap harga saham pada perbankan yang terdaftar di BEI.

5. ROA, DER, PBV dan NPM secara bersama- sama terdapat pengaruh terhadap harga saham pada perbankan yang terdaftar di BEI.

\section{Limitasi dan Studi Lanjutan}

Penelitian ini mengalami keterbatasan pada data yang diolah, dan pada variable yang dipakai. Bagi penelitian berikutnya dapat meneliti variabel lainnya yang dapat mempengaruhi harga saham, misalkan tentang Return On Equity (ROE), Current Ratio, dan faktor - faktor lain, ditambah subjek penelitian di atas tahun 2017 serta meneliti pada sector manufaktur lainnya,

7. Ucapan terima kasih

Peneliti menyampaikan terima kasih kepada berbagai pihak yang telah membantu penelitian ini, khususnya kepada LPPM Institute Business Informatika Kesatuan Bogor (IBIK) Bogor.

\section{REFERENSI}

Aditya, Pratama, dan Teguh. (2014). Pengaruh Current Ratio, Debt To Equty Ratio, Return On Equity, Net Profit Margin dan Earning Per Share Terhadap Harga Saham ( Studi Kasus Pada Perusahaan Manufaktur yang Terdaftar di Bursa Efek Indonesia Periode 2008 - 2011). Makalah. Jurnal Akuntansi Vol 2 No 1 Juni 2014. 


\section{Seminar Ilmiah Sistem Informasi Manajemen dan Akuntansi (SISIMA) 2021

Sartono, Agus. (2011). Manajemen Keuangan Teori dan Aplikasi . Yogyakarta: BPFE

Brigham, Eugene, dan Houston. (2009). Dasar - Dasar Manajemen Keuangan. Salemba Empat, Jakarta.

Brealey, Myer, Marcus (2006). Dasar - Dasar Manajemen Keuangan Perusahaan. Erlangga. Jakarta.

Daniarto, Rahardjo, dan Dul Muid. (2013). Analisis Pengaruh Faktor - faktor Fundamental Rasio

Keuangan Terhadap Perubahan Harga Saham. Journal Of Accounting Diponegoro Volume 2 No 2.

Darmadji, Fakhrudin. (2012). Pasar Modal di Indonesia. Edisi Ketiga. Jakarta : Salemba Empat.

Fahmi, Irham. (2012). Analisis Laporan Keuangan . Alfabeta. Bandung.

Harahap, S. S. (2010). Analisis Kritis Atas Laporan Keuangan. PT. Raja Grafindo Persada. Jakarta.

Hartono, Jogiyanto. (2013). Teori Portofolio dan Analisis Investasi. BPFE . Yogyakarta.

Hery. (2014). Akuntansi Dasar 1 dan 2. Jakarta: Kompas Gramedia

Harmono. (2017). Manajemen Keuangan Berbasis Balanced. Jakarta : PT Bumi Angkasa Raya

Jensen, M. C., dan Meckling, W. H. (1976). Theory of the Firm: Managerial Behavior, Agency Costs and Ownership Structure. Journal of Financial Economics, 3 (4), 305-360.

Khasmir. (2009). Analisis Laporan Keuangan , Rajawali Pers jakarta

Munawir, S. (2012). Analisis Informasi Keuangan . Liberty. Yogyakarta.

Prasetyo, Moektiono, Putro. (2017). Analisis Pengaruh Rasio Keuangan Terhadap Harga Saham Pada Perusahaan Manufaktur yang Terdaftar di Bursa Efek Indonesia. Universitas Muhammadiyah Surakarta.

Putu, Dina Aristya, dan Igna Suaryana .(2013). Pengaruh EPS, DER, Dan PBV Terhadap Harga Saham. E-Jurnal Akuntansi Universitas Udayana.

Rescyana, Putri Hutami. (2012). Pengaruh Dividen Per Share , Return Om Equity dan Net Profit Margin terhadap Harga Saham Perusahaan Industri Manufaktur Yang Tercatat di Bursa Efek Indonesia Periode 2006 - 2010 . Makalah. Jurnal Nominal Volume 1 No 1.

Rita, Widayanti, dan Fredella Colline. (2017). Pengaruh Rasio Keuangan Terhadap Harga Saham Perusahaan LQ 45 Periode 2011 - 2015. Makalah. Jurnal Bina Ekonomi.

Robert, Lambey. (2014). Analisis Pengaruh Rasio Keuangan Terhadap Harga Saham Pada Bank di Bursa Efek Indonesia . Makalah. Jurnal Accountability Universitas Sam Ratulangi Manado.

Sugiyono, (2013). Metode Penelitian Kuantitatif, Kualitatif dan R\&D. Penerbit Alfabeta, CV Bandung

Sugiyono, (2013). Metode Penelitian Kuantitatif, Kualitatif dan R\&D. Penerbit Alfabeta, CV Bandung

Warsani, Purnama Sari. (2018). Pengaruh Rasio Keuangan Terhadap Harga Saham Pada Perusahaan Manufaktur Go Public Yang Terdaftar di Bursa Efek Indonesia. Jurnal Ilmiah Skylandsea. Jurnal Bisnis dan Ekonomi: 142-151 